\title{
The role of perceived risk in influencing online shopping attitude among women in India
}

Nupur Arora* and Manmohan Rahul

School of Management Studies,

Ansal University,

Gurugram, Haryana, India

Email: nupur.arora1510@gmail.com

Email: manmohanrahul@ansaluniversity.edu.in

*Corresponding author

\begin{abstract}
The objective of this research study is to examine the key components of perceived risk (security risk, privacy risk, product risk and non delivery risk) in ecommerce and the impact of perceived risk on online shopping attitude among online women shoppers in India. It proposes a model explaining how perceived risk in online shopping impacts attitude and what is the impact of online shopping attitude on online shopping intention. Sample size of 508 women shoppers was considered in the study and the technique of Structural equation modelling was employed. An online questionnaire was administered at internet users who had prior online shopping experience. Confirmatory factor analysis was used to evaluate the research constructs, validity and composite reliability. The results of the study demonstrate that perceived risk is not a significant factor influencing attitude of women shoppers in India. Security risk was marginally significant out of the different types of risks considered in the study.
\end{abstract}

Keywords: online shopping attitude; OSA; online purchase intention; e-commerce; perceived risk; security; privacy; product; India.

Reference to this paper should be made as follows: Arora, N. and Rahul, M. (2018) 'The role of perceived risk in influencing online shopping attitude among women in India', Int. J. Public Sector Performance Management, Vol. 4, No. 1, pp.98-113.

Biographical notes: Nupur Arora holds a gold medal in management from the Amity University. She is an Assistant Professor in the Vivekananda School of Professional Studies, Delhi and a research scholar from the Ansal University, Gurugram, India. She is a member of the Insurance Institute of India. Her areas of expertise are insurance and marketing.

Manmohan Rahul is a Postgraduate in Statistics, MBA degree from the FMS Udaipur and FDP in Management from the IIM Ahmedabad. He has received his Doctorate degree in International Business (Applied Economics Area) from the Agra University. He started his career with the Telco in the year 1996 and thereafter sought career in academics. His areas of interest are general management, international business, production and operation management and quantitative techniques for management. His interest also lies in writing cases and case analysis. 


\section{Introduction}

Online retail is a budding but fast growing retail model in numerous countries around the world, especially in developing economies. The pace at which it is emergent is leading to rigid competition among vendors in online market space. Firms today acknowledge that they only low prices and rigorous marketing cannot give them a competitive edge they are eager to attain. They need to discover other effective ways of differentiating themselves so as to attract more customers and enhance their satisfaction with their online stores. The risk component in online shopping is immense as the nature of transaction is intangible. Thus reducing the perceived risk among consumers towards online transactions shall be of paramount importance for online vendors. Efforts in this direction would compliment other benefits provided by online retailers.

Thus the paper has the following research objectives:

1 to study the important components of perceived risk in e-commerce

2 the impact of perceived risk on online shopping attitude (OSA)

3 the impact of OSA on online shopping intentions.

\subsection{Theoretical framework: theory of reasoned action}

The theory of reasoned action (TRA) was proposed by Fishbein (1960) and further expanded by Fishbein and Azjen (1980). The theory centres on an individual's intention to behave a certain way. According to the proposed theory, an explicit behaviour can be foreseen if two critical components, namely, subjective norms and actor's attitude are identified or known. Attitude is further determined by two variables-normative beliefs and motivation to comply. "Normative beliefs are a person's perception to what significant others think, believe or do" (Petty and Cacioppo, 1981).

Figure 1 Theory of reasoned action

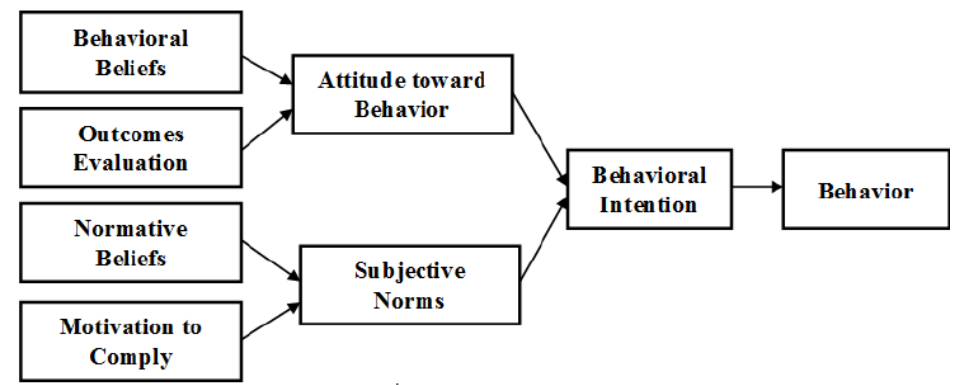

Source: Azjen and Fishbein (1980)

The model has been employed and tested in many settings and situations by renowned researchers. A few of them include the area of contraceptive use (Miller and Grush, 1986), moral behaviour (Marin et al., 1990; Chang, 1998) and the field of consumer behaviour (Anilkumar and Joseph, 2012; Smith et al., 2008; Ming-Shen et al., 2007). 


\section{Online buying behaviour}

As indicated by Schibrowsky et al. (2007), online shoppers' behaviour is one of the main four research areas in the field of online marketing studies. The domain of internet shopping research has ended up being an important research curiosity for the online customer behaviour area as of late, particularly in India where this industry is at a developing stage. Cheung et al. (2005) compiled the studies performed in the field of web based shopping and they suggested the key determinants of online buyer conduct as-consumer qualities, environmental influences, product/benefit properties, medium attributes and intermediary qualities.

Shopping orientation as component of online consumer behaviour has additionally been a field of curiosity in past research studies. Babin et al. (1994) suggested two critical purchasing motives-shopping for fun, i.e., hedonic reasons and aim orientated purchasing, i.e., utilitarian reasons. On an online platform additionally the customers can be segmented as hedonic and utilitarian shoppers and studies has been performed to take a look at the behaviour of these buyers (Childers et al., 2001; Park and Sullivan, 2009; Sarkar, 2011)

Past Research clearly provides verification that shopping through online mode is recently being preferred by shoppers and like online shopping activities very often. Ramsey et al. (1999) studied the patron preference of in-store versus online shopping employing panel data. Their results recommend that with time there was a rise in individuals buying online (Ramsey et al., 1999). Another study divides on-line shoppers into four distinct segments-never buy, dropouts, newbies and steadfast buyers (Lohse et al., 2000). Kiran et al. (2008) explored the ever-changing trends of online shopping in India. Their study disclosed that there's a growing awareness among individuals to assemble additional data through websites .There is a rising tendency to shop for tickets, books and music on-line, still a really miniscule share of web users like online shopping for activities. The most regular reasons for online shoppers to buy through the internet are: convenience, followed by saving time, curiosity, availability of merchandise service information and no pressure from the salesmen (Zhou et al., 2007). Chiang (2001) too support this argument. Their study suggests that convenience and price strongly influence consumers' intention to buy online. The category of product also significantly contributes to consumer preference to shop online. Low price and regularly purchased merchandise are purchased more over the online medium in comparison to high price and less frequently purchased merchandise (Phau et al., 2000).

Extrapolating from the above background, research in the electronic commerce domain has gain importance recently and researchers are trying to explore the behaviour elicited by consumers in the entire process of ecommerce transaction.

\subsection{Online purchase intention}

As cited in the TRA, attitude leads to behavioural intention and which in turn leads to actual behaviour (Ajzen and Fishbein, 1980). Online purchase intention is defined as the construct that gives the strength of a customer's intention to purchase online (Salisbury et al., 2001). To trigger purchase intention among customers and converting it to actual purchase behaviour is an important area for the web retailers to study and they should try to enhance those factors which contribute significantly to formation of positive purchase intention. OSA is an important antecedent in formation of online purchase intention 
which has been reiterated by researchers in the past (Park, 2003; Zimmer et al., 2010; Delafrooz et al., 2011; Hsu et al., 2013; Akroush and Al-Debei, 2015).

Thus the following hypothesis is proposed:

H1 There is a significant positive impact of OSA on online purchase intention among women.

\subsection{Perceived risks}

The concept of perceived risk was initially investigated in the background of non store consumer behaviour. The pioneers in contributing to the studies at this phase were Cunningham (1967), Jacoby and Kaplan (1972). During this phase of research, perceived risk was separated into five dimensions- social, psychological, physical, financials and performance risk. Peter and Tarpey (1975) contributed one more element to the concept of perceived risk - time risk. With the increasing emergence of e-commerce as a medium of retail, three more dimensions of perceived risk - privacy risk, security risk and source risk or e-retailer's risk were added by researchers. Featherman and Pavlou (2003) proposed that in the e-service context, performance, financial, privacy and time risk were the chief reasons of concern.

Regardless of the benefits of ecommerce over traditional commerce and positive prediction for future expansion of online shopping, negative characteristics connected with this shopping process are also becoming significant as well as critical (Ko et al., 2004).

Risk plays a crucial role in the field consumer behaviour and it makes a $\mathrm{n}$ important contribution towards elucidating the information-searching behaviour of the consumers and the final consumer purchase decision making. There are two diverse theoretical perspective about risk: one that focuses on a decision results ambiguity and another focused on the costs or consequences of such results (Barnes et al., 2007).Although consumers identify the Internet as a beneficial medium for shopping, the internet tends to expand some of the reservations associated with any purchase process. "Consumers perceive a higher level of risk when purchasing on the Internet compared with traditional retail formats" (Lee and Tan, 2003).

The idea of perceived risk has been studied by applying different scales by measuring the perception of dangerous events occurring (Featherman and Pavlou, 2003). Perceived risk diminishes the interest of consumers to buy goods over the internet (Barnes et al., 2007). Greater perception of risk on the part of consumers' acts as a restriction to their purchase intentions. Several authors have observed that the perceived risk in e-commerce has a negative effect on shopping behaviour on the internet, attitude toward usage behaviour and intention to adopt e-commerce (Zhang et al., 2012).

Perceived risk is an important contributing factor to trust in online context and the former effects online buying intentions members (Thakur and Srivastava, 2015). Hsu et al. (2014) reported in their research of 242 respondents that four types of trust are critical determinants of perceived risk and attitude which are namely trust in website, trust in vendor, trust in, auction initiator and trust in group members.

The term risk in ecommerce is generally associated with loss of financial information or identity theft over the ecommerce platform. Perceived risk of information security and privacy are key elements in the process of buying through the internet (Rapp et al., 2009) 
Researchers broadly agree to the fact that that perceived risk is a permutation of the perception of the likelihood that something will go wrong and the perception of the seriousness of the consequences (Kaplan et al., 1974; Taylor, 1974; Bettman, 1973). Perceived risk is an element that forms trust and trust is an element of attitude formation typically in the context of e-commerce forms. Thus we can say it indirectly effect of OSA of consumers.

There are many severe issues that discourage consumers from shopping online. Past research recommend that fear of fraud, absence of standard technologies for secure payment, privacy issues and lack of overall trust in e-commerce were the major reasons consumers opt out of engaging in an online marketplace (Chen and Tan, 2004; Hoffman et al., 1999; Lee and Turban, 2001; Olivero and Lunt, 2004; Ranganathan and Jha, 2009; Riegelsberger et al., 2005). A research study conducted by the Princeton Survey Research Associates International in 2007 discovered that sending personal or credit card information were two of the major factors influencing the probability that Americans will execute an online transaction (Horrigan, 2008). Perceived risk is influenced numerous of factors. As pointed out by many researchers (Gerrard and Cunningham, 2003; Kim and Forsythe, 2010), several types of perceived shopping risks act as a hindrance in carrying out internet-based transactions and it finally influences the choice of medium customer chooses to shop. These are performance risk, time risk, social risk, financial risk, security risk and privacy risk (Thakur and Srivastava, 2015).

Financial risk - the risk related to loss of money (Lee et al., 2001; Fram and Grady, 1997) It is defined as "potential net loss of money and includes consumers 'sense of insecurity regarding online credit card usage, which has been evidenced as a major obstacle to online purchases" (Maignan and Lukas, 1997).

Privacy risk - privacy and security are two clearly divergent constructs (Miyazaki and Fernandez, 2001; Belanger et al., 2002). Privacy risk means the risk that an online vendor may share the personal information of the customer with external parties or misuse it. Perceived privacy risk is defined as "the possibility that online businesses might use personal information inappropriately hence invading a consumer's privacy" (Nyshadham, 2000). Thus the perception of the consumer of the credibility of security and privacy may influence e-commerce use intention (Mukherjee and Nath, 2003). A study in the USA indicates that $92 \%$ concerned about their privacy when using the internet (TRUSTe, 2015). In India as well consumers are aware and concerned about their internet privacy. Another study revealed that $70 \%$ of consumers surveyed worldwide were concerned about the personal privacy online (J.D Power and Associates, 2013).

Security risk - security pertains to how secure the financial transactions over the internet are. In other words it is the perceptions about security concerning the ways of payment and the method for storing and transmission of information (Kolsaker and Payne, 2002). Perceived online security is "the internet users' perception on the Internet vendors' ability to fulfil security requirements" (Cheung and Lee, 2001).

Performance risk/product risk - the risk associated with the fundamental working or aspect of a product that whether it will perform as per expectations or not (Jacoby and Kaplan, 1972; Spence et al., 1970, Forsythe et al., 2006). Due to the very nature of online transactions, i.e., intangibility and the inability of the customer to touch, feel and try the product this type of risk is inherent to e-commerce transactions. 
Non-delivery risk - "probable loss of delivery associated with goods lost, goods damaged and sent to the wrong place after shopping" (Yu et al., 2007). Online shoppers fear that delivery might be delayed because to a variety of reasons; the company responsible for delivery will not deliver the product within the time frame updated to the customers, or consumers might fear that the goods may be damaged while in transit, or no proper packaging and handling during transportation (Claudia, 2012).

Elucidating from the above literature, the following hypothesis is proposed:

H2 Perceived risk has a significant impact on OSA among women in India.

Figure 2 Proposed research model

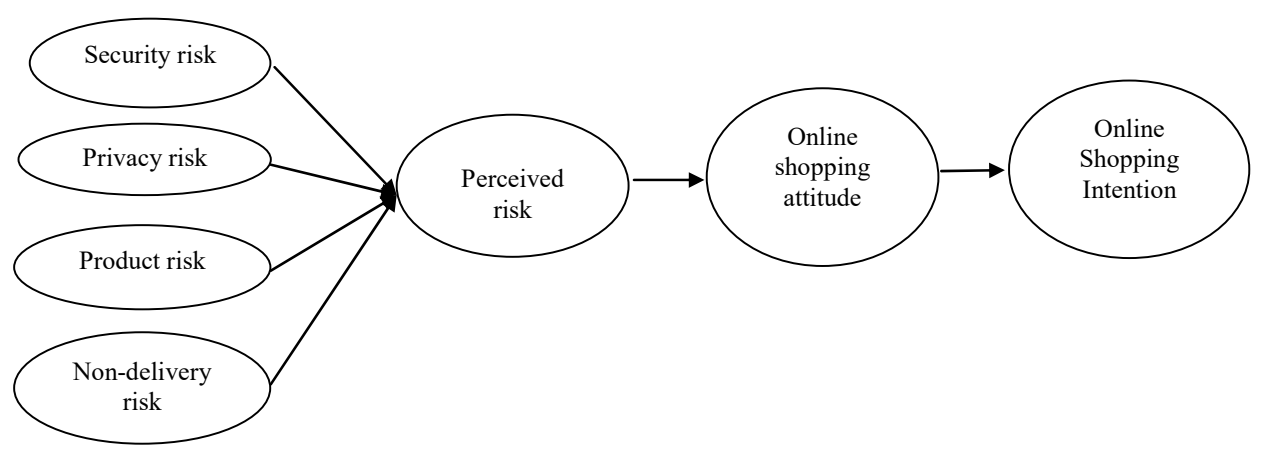

A lot of past research has been conducted on the influence of perceived risk on attitude of consumers but no study has been yet conducted to study the same in the Indian context and that too on women shoppers. This study aims to study the influence of perceived risk on OSA among women online shoppers which is an attempt to fill this research gap.

\section{Conceptual model}

Our research model is illustrated by Figure 2, in which it is hypothesised that for women online shoppers, intention to shop online is determined by attitudes attitude towards online shopping is influenced by perceived risk in online shopping which comprise of four types of risk (security risk, privacy risk, product risk and non delivery risk).

Table 1 Summary of the effect of antecedents on the attitude of online shopping

\begin{tabular}{llc}
\hline Constructs & \multicolumn{1}{c}{ Authors } & Summary of findings \\
\hline $\begin{array}{l}\text { Online purchase } \\
\text { attitude and intention }\end{array}$ & $\begin{array}{l}\text { Ajzen and Fishbein (1980), Korzaan } \\
(2003), \text { Park (2003), Zimmer et al. } \\
(2010), \text { Delafrooz et al. (2011), Hsu et al. } \\
\text { (2013), Akroush and Al-Debei (2015) }\end{array}$ & $\begin{array}{c}\text { Attitude is one of the } \\
\text { critical factors influencing } \\
\text { online purchase intention. }\end{array}$ \\
& Jarvenpaa and Todd (1997), Kimery and & Perceived risk is an \\
Perceived risks & $\begin{array}{l}\text { McCord (2002),Van der Heijden et al. } \\
\text { (2003), Thakur and Srivastava (2015), }\end{array}$ & $\begin{array}{c}\text { important antecedent } \\
\text { influencing online } \\
\text { purchase attitude }\end{array}$ \\
\hline
\end{tabular}




\section{Methodology}

\subsection{Data collection and sample}

With the intention of test the study model and, we applied a quantitative study based on an online questionnaire in the Indian context. The aim of the online survey was to collect responses from internet users who had made an online purchase in the past.

Four metropolitan cities were considered for sample collection - Delhi, Mumbai, Bangalore and Kolkata. These cities were selected to reduce bias and to include distinct parts of the country.

The survey was distributed through social networking sites such as Facebook and Twitter, e-mails and mobile messenger applications like Whatsapp, Snapchat and Viber. The method of sampling employed was non-random sampling. These survey media were selected because of their extensive reach and popularity in India. The posting message primarily invited female online shoppers to respond to the online questionnaire. The link was open for respondents for one month and the respondents could fill the response at any point during that period clicking the survey URL provided on the message. The participants willingly responded to online questionnaire. After one month to get an effective response data the unusable responses were deleted that included incomplete questionnaire, duplicate IP addresses and e-mail accounts.

The sampling method employed for the survey is purposive non probability sampling.

A basic characteristic of non-probability sampling technique is that the samples are chosen based on the subjective opinion of the researcher, rather than random selection

"Purposive sampling is described as a random selection of sampling units within the segment of the population with the most information on the characteristic of interest" (Guarte and Barrios, 2006). Purposive sampling can be used with a number of techniques in data gathering (Godambe, 1982). A research study may be initiated with a survey and then purposive sampling done based on the survey (Brown, 2005). According to Tongco (2007) if the information which the researcher requires is held by only few members of the community the method to be employed is purposive sampling.

The current research study attempts to study the attitude of only online shoppers and that too only for women. Thus the sampling method is justified according to the above argument.

\subsection{Measurement development}

The questionnaire was divided into two parts: demographic profile of the survey respondents and constructs items. Particularly, the demographic section asked the respondents personal profile as well as two additional questions asking the type of product they buy online and their prior online shopping experience. Additionally, to develop scales for measuring various constructs identified in the study such as attitude, intention to shop online, security risk, privacy risk, product risk and non delivery risk, we utilised modified scales from past research. Table 2 illustrates the references from which the measurement scale has been adapted and they have been modified as per the study.

Each statement in the questionnaire was d-measured on a nine-point Likert scale, ranging from 'strongly disagree' (1) to 'strongly agree' (9). Before conducting the focal study survey, a pre-test was conducted which included a sample of 85 women online 
shoppers from different age groups across four metropolitan cities of India - Delhi, Mumbai, Bangalore and Kolkata. The phrasing of the scales, the length of the survey instrument and the layout of the questionnaires were amended in pre-test process to attain the final adaptation of the survey. Lastly, to minimise possible uncertainty and ambiguity in the items, a pilot test involving 85 female respondents, selected from a population of online shoppers, was administered. The results of the pilot tests displayed acceptable reliability and validity of the measurement scale.

Table 2 Measurement scale adaptation

\begin{tabular}{lc}
\hline Construct & Adaptation \\
\hline Perceived risk & Ford (2004) \\
Security risk & Forsythe et al. (2006), Sinha (2010) \\
Privacy & Forsythe et al. (2006), Sinha (2010) \\
Product risk & Masoud (2013) \\
Non-delivery risk & Sinha (2010), Hsu et al. (2014), Van der Heijden et al. (2003) \\
Online shopping attitude & Kim et al. (2004), Fishbein and Ajzen (1975) \\
Online shopping intention &
\end{tabular}

\section{Results}

\subsection{Descriptive statistics}

Table 3 records the means as well as the standard deviations of the constructs. It can be observed that, typical, the participants responded positively to the study constructs (the averages all being $>3$ ).

Table 3 Descriptive statistics (means and SD)

\begin{tabular}{lccc}
\hline Constructs & Mean & SD & Cronbach's $\alpha$ \\
\hline Online shopping attitude & 4.872 & 1.441 & 0.835 \\
Online shopping intention & 4.703 & 1.452 & 0.830 \\
Security risk & 5.28 & 2.292 & 0.859 \\
Privacy risk & 5.57 & 2.158 & 0.879 \\
Product risk & 5.88 & 2.156 & 0.915 \\
Non-delivery risk & 5.41 & 2.216 & 0.825 \\
\hline
\end{tabular}

Furthermore, the coefficient values for all constructs are exceeding the conventional value of 0.7 (Nunnally, 1987); the measurement scales for these constructs demonstrated a satisfactory level of reliability.

Table 4 illustrates the complete research sample profile. Clearly, Table 4 demonstrates that $47.6 \%$ of the sample bought from three to five times using the website. This is a critical outcome which indicates the respondents are familiar with online shopping.

Also, Table 4 shows that almost two-third of the sample are aged between 24 and 37. 
Table 4 Demographic profile

\begin{tabular}{lccc}
\hline Measure & Items & Frequency & Percentage \\
\hline I am using internet for shopping since & Never & 1 & 2 \\
& Past 6 months & 88 & 13.9 \\
& Past 1 year & 121 & 19.1 \\
& More than 1 year & 298 & 47.1 \\
Age & $24-30$ & 254 & 50 \\
& $31-37$ & 169 & 33.2 \\
Annual income & $38-45$ & 80 & 15.7 \\
& $>46$ & 5 & 0.9 \\
& $0-2.5$ lac & 35 & 6.8 \\
Marital status & $2.5-5$ lac & 131 & 25.7 \\
& $5-10$ lac & 308 & 60.7 \\
& Above 10 lac & 34 & 6.69 \\
& Married & 272 & 53.6 \\
& Unmarried & 235 & 46.4 \\
\hline
\end{tabular}

\subsection{Construct validity}

For any research study to be applicable, it is important to test the validity of the research instrument applied in a research study. The validity of the study instrument was estimated through content, face, convergent and discriminant validity. The assessment of face validity was carried out through a pilot study of the research instrument with a number of Indian online shoppers including only women. In addition, the research study instrument was scrutinised by two academic experts from reputed business schools as well as three online shopping experts who verified the significance and suitability of the questionnaire to realise the research objectives. Content validity is substantiated by amplifying the methodology used to develop the study questionnaire (Churchill, 2001), which incorporated two steps. First, investigating the previous empirical and theoretical research work of attitudes toward online shopping; and second, performing the pilot test before starting the fieldwork. With regard to construct validity, as advocated by Hair et al. (1998), the technique of exploratory factor analysis (EFA) and confirmatory factor analysis (CFA) are employed. In the present study since the previous literature is evident of the factors contributing to trust; only CFA is employed in the current study. It has been suggested in literature that CFA, derived from structural equation modelling (SEM), is a meticulous test of unidimensionality (Garver and Mentzer, 1999).

The results in Table 5 indicate that the $\mathrm{p}$ values of all the statements used in the scale are less than $5 \%$ level of significance. Hence with $95 \%$ confidence level it can be concluded that all the statements used in the scale in order to measure the different constructs are significantly represents the constructs. 
Figure 3 SEM model for perceived risk and OSA and intention (see online version for colours)

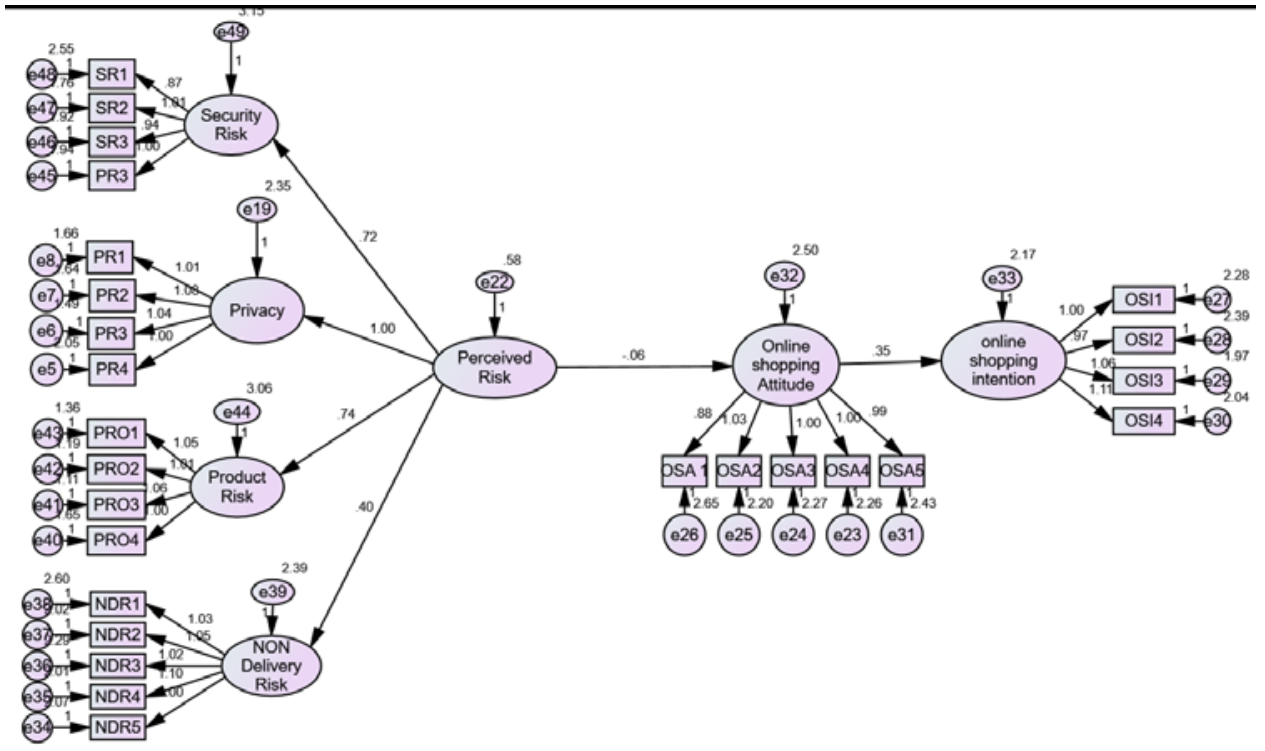

\subsection{Structural model and hypotheses testing}

In the research study perceived risk ecommerce is studied and measured with the help of four first order constructs. These first order constructs are named as security risk, privacy risk, product risk and non-delivery risk. The different statements of these first order constructs are incorporated in the questionnaire in order to get primary responses from women shoppers . The responses are collected on the scale of continuous scale of 1 to 9 where 1 stands for strongly disagree and 9 for strongly agree. The SEM technique is applied in the study on order to analyse the cause and effect relationship between perceived risk on OSA and the impact of OSA on online shopping intention. In the SEM model the, OSA is considered as an endogenous construct and the three first order constructs measuring trust as a second order construct. The SEM diagram is shown below in Figure 2.

The results in Table 6 indicate that in case of the impact of perceived risk on OSA (OSA) the $\mathrm{p}$ value of critical ratio is found to be more than $5 \%$ level of significance. Hence, it can be suggested that perceived risk do not have significant impact on OSA.

To evaluate the CFA, goodness of measurement model fit using SEM were pursued [Chau, (1997), p.318]: $\chi 2$ ( $\mathrm{p} \geq 0.05)$; goodness-of-fit index (GFI $\geq 0.90$ ); adjusted goodness-of-fit index (AGFI $\geq 0.80$ ); normed fit index (NFI $\geq 0.90$ ); non-normed fit index (NNFI $\geq 0.90)$; comparative fit index (CFI $\geq 0.90)$; standardised root mean square residual (SRMR $\geq 0.08$ ); and root mean-square error of approximation (RMSEA $<0.10$ ). The statistical fitness of the SEM model is shown below in Table 6. 
Table 5 Hypothesis testing

\begin{tabular}{lllccccc}
\hline Hypothesis path & & & $\begin{array}{c}\text { Standardised } \\
\text { beta estimate }\end{array}$ & SE & CR & $P$ \\
\hline Online_shopping_attitude & $<---$ & Perceived_risk & -0.03 & 0.185 & -0.338 & 0.736 \\
Privacy & $<---$ & Perceived_risk & 0.446 & & & \\
online_shopping_intention & $<---$ & Online_shopping_attitude & 0.353 & 0.055 & 6.363 & $* * *$ \\
NON_delivery_risk & $<---$ & Perceived_risk & 0.195 & 0.244 & 1.653 & 0.001 \\
Product_risk & $<---$ & Perceived_risk & 0.308 & 0.393 & 1.885 & 0.025 \\
Security_risk & $<---$ & Perceived_risk & 0.295 & 0.379 & 1.887 & $* * *$ \\
\hline
\end{tabular}

Table 6 The statistical fitness of the SEM model

\begin{tabular}{lccc}
\hline$C M I N / D F$ & $G F I$ & $C F I$ & $R M S E A$ \\
\hline 1.353 & 0.943 & 0.983 & 0.026 \\
\hline
\end{tabular}

The results in Table 6 specify that CMIN/DF (1/1.353) if found to be less than 5, indicating the good statistical fitness of the model. Similarly the GFI statistics of the model is found to be 0.9643 which is close to 9. CFI statistics greater than 0.9 and RMSEA value less than 0.08 , which indicates that the SEM model is statistically fit and can be used for practical purposes.

\section{Discussion and implications}

India, a culturally-diverse nation with many different ethnicities, has an enormous population base from which to single out entrepreneurial personalities. Organisations such as the progress harmony development chamber of commerce and industry and the entrepreneurship development institute of India are working diligently at laying the foundations for creating entrepreneurs in this country (Dana, 2000).

Previous literature suggested that perceived risk that when consumers see potential risk in the purchase of a good or service, there might be uncertainty about the outcome of their decision, or concern about the consequences of their decision (Ko et al., 2004; Barnes et al., 2007). Contrary to the literature, the results of the present study indicate that perceived risk does not have any significant impact on OSA among women shoppers in India. On the other hand, OSA was found to have a significant positive impact on online shopping intention which is consistent with the past studies (Ajzen and Fishbein, 1980; Park, 2003; Zimmer et al., 2010; Delafrooz et al., 2011; Hsu et al., 2013).

The study also confirms the three elements of perceived risk, namely, security risk, privacy risk, product risk and non delivery risk. This finding enriches the understanding on behaviour of women consumers in India who indulge in online purchase. The perceived risk of women in online shopping does not influence OSA to a great extend. There are many reasons for this phenomenon. The security risk is lower nowadays as the e-banking transactions are more secure. Each online transaction is secured by multiple passwords. Availability of payment gateways such as Paypal, Mobiwik, PayUmoney have reduced the security risk of ecommerce transactions to a great extend. Even of the customer is not comfortable in sharing the financial details, they can choose for cash on delivery payment mode to reduce the security risk in the purchase transaction. The 
privacy risk is also not of importance to consumers as now ecommerce websites also have an option of 'continue as guest' and it is not mandatory to fill personal details of the customer apart from basic contact details. The websites mention their privacy policies as a separate section on their web pages which also reduce the risk of losing private information to unwanted parties. Last but not the least; since ecommerce transactions are now very common in metropolitan cities of India, the consumer is now not much particular to provide their basic personal information.

Elaborating about product risk, shoppers do not consider it as a huge risk as the quality of product presentations have improved immensely in the past few years which gives a clear idea of the product. The product details are also clearly mentioned on websites such as dimensions, material, fabric etc. Additionally, easy and flexible return and exchange policies have eliminated this type of risk in e-commerce transactions. Ecommerce vendors are offering 15 to 30 days exchange and return to retain customer which further reduces the risk associated with the product. Finally, the risk associated with non delivery of mere importance as online tracking systems of the shipment are accessible to the consumer which makes it very convenient to check the exact location of the product. Thus this has contributed to diminish the risk associated with in delivery of the product. The cash on delivery mechanism also aids in reduction of non delivery risk since the customer can pay on delivery only when he or she receives the product.

Innovative terms can be incorporated in return and exchange policies to further reduce the risks.

\section{Conclusions and future research}

This research study was one of the few attempts to explore the impact of perceived benefits on OSA and purchase intentions. The study explained that in the present scenario, Indian female shoppers do not consider perceived risk as an important factor influencing their OSA. Consistent with past literature, OSA was found to have significant positive impact on online shopping intentions.

There is a scope of future research is immense in this area. Future research can be directed towards comparative studies. Direct comparisons between developing economies such as India and highly developed economies such as the USA or UK will disclose the noticeable differences that exist and provide on outlook both within the domestic market as well as between different markets. Additionally, comparisons between comparable emerging markets for instance India and China shall be of great value in the same way. The budding Indian marketplace offers a brilliant prospect for longitudinal research studies in this field. Also, a comparison between the two genders can also open plethora of new insights in the field of online shopping research.

\section{References}

Ajzen, I. and Fishbein (1980) Understanding Attitudes and Predicting Social Behavior, Prentice-Hall, Upper Saddle River, NJ.

Akroush, M.N. and Al-Debei, M.M. (2015) 'An integrated model of factors affecting consumer attitudes towards online shopping', Business Process Management Journal, Vol. 21, No. 6, pp.1353-1376. 
Anilkumar, N. and Joseph, J. (2012) 'An insight into modern consumer attitude - a study with specific reference to consumer durables at Kochi metro', ASBM Journal of Management, Vol. 5, No. 2, pp.1-12.

Babin, B., Darden, W. and Griffin, M. (1994) 'Work and/or fun: measuring hedonic and utilitarian shopping value', Journal of Consumer Research, Vol. 20, No. 1, pp.644-656.

Barnes, S.J., Bauer, H.H., Neumann, M.M. and Huber, F. (2007) 'Segmenting cyberspace: a customer typology for the internet', European Journal of Marketing, Vol. 41, Nos. 1/2, pp.71-93.

Belanger, F., Hiller, J.S. and Smith, W.J. (2002) 'Trustworthiness in electronic commerce: the role of privacy, security, and site attributes', The Journal of Strategic Information Systems, Vol. 11, No. 3, pp.245-270.

Bettman, J.R. (1973) 'Perceived risk and its components: a model and empirical test', Journal of Marketing Research, May, Vol. 10, pp.184-190.

Brown, K.M. (2007) 'Reconciling moral and legal collective entitlement: implications for community-based land reform', Land Use Policy, Vol. 24, No. 4, pp.633-643.

Chang, M.K. (1998) 'Predicting unethical behavior: a comparison of the theory of reasoned action on the theory of planned behavior', Journal of Business Ethics, Vol. 17, No. 16, pp.1825-1834.

Chau, P. (1997) 'Reexamining a model for evaluating information centre success using a structural equation modelling approach', Decision Sciences, Vol. 28, No. 2, pp.309-333.

Chen, L.D. and Tan, J. (2004) 'Technology adaptation in e-commerce: key determinants of virtual stores acceptance', European Management Journal, Vol. 22, No. 1, pp.74-86.

Cheung, C.M. and Lee, M.K. (2001) 'Trust in internet shopping: instrumental development and validation through classical and modern approaches', Advanced Topics in Global Information Management, Vol. 9, No. 3, pp.25-41.

Cheung, C.M., Chan, G.W. and Limayem, M. (2005) 'A critical review of online consumer behavior: empirical research', Journal of Electronic Commerce in Organizations, Vol. 3, No. 4, p.1.

Chiang, K.P. (2001) 'Effects of price, product type and convenience on consumer intention to shop online', in American Marketing Association, Conference Proceedings, American Marketing Association, January, Vol. 12, p 163.

Childers, T.L., Carr, C.L., Peck, J. and Carson, S. (2002) 'Hedonic and utilitarian motivations for online retail shopping behavior', Journal of Retailing, Vol. 77, No. 4, pp.511-535.

Churchill, G. (2001) Basic Marketing Research, 4th ed., The Dryden Press, Fort Worth, TX.

Claudia, I. (2012) 'The mediating role of perceived risk when buying online', Acta Universitatis Danubius. Economica, Vol. 8, No. 5, pp 1317-1322.

Cunningham, L.F., Gerlach, J.H., Harper, M.D. and Young, C.E. (2005) 'Perceived risk and the consumer buying process: internet airline reservations', International Journal of Service Industry Management, Vol. 16, No. 4, pp.357-372.

Cunningham, S.M. (1967) 'The major dimensions of perceived risk', Risk Taking and Information Handling in Consumer Behavior, Vol. 1, No. 2, pp.82-111.

Dana, L.P. (2000) 'Creating entrepreneurs in India', Journal of Small Business Management, Vol. 38, No. 1, p.86.

Delafrooz, N., Paim, L.H. and Khatibi, A. (2011) 'Understanding consumer's internet purchase intention in malaysia', African Journal of Business Management, Vol. 5, No. 7, pp.2837-2846 [online] DOI: http://dx.doi.org/10.5897/AJBM10.1266 (accessed 15 June 2016).

Featherman, M.S. and Pavlou, P.A. (2003) 'Predicting e-services adoption: a perceived risk facets perspective', International Journal of Human-Computer Studies, Vol. 59, No. 4, pp.451-474.

Fishbein, M. and Ajzen, I. (1975) Belief, Attitude, Intention and Behavior: An Introduction to Theory and Research, Addison-Wesley, Reading, MA. 
Ford, D. (2004) Purchasing Habits on the Internet by Gender: Issues, Perceptions and Reasons Regarding Gender-Based Online Shopping Behaviors, Doctoral dissertation, Walden University.

Forsythe, S., Liu, C., Shannon, D. and Gardner, L.C. (2006) 'Development of a scale to measure the perceived benefits and risks of online shopping', Journal of Interactive Marketing, Vol. 20, No. 2, pp.55-75.

Fram, E.H. and Grady, D.B. (1997) 'Internet shoppers: is there a surfer gender gap?', Direct Marketing-Garden City, Vol. 59, No. 1997, pp.46-51.

Garver, M. and Mentzer, J. (1999) 'Logistics research methods: employing structural equation modelling to test for construct validity', Journal of Business Logistics, Vol. 20, No. 1, pp.33-47.

Gerrard, P. and Barton Cunningham, J. (2003) 'The diffusion of internet banking among Singapore consumers', International Journal of Bank Marketing, Vol. 21, No. 1, pp.16-28.

Godambe, V.P. (1982) 'Estimation in survey sampling: robustness and optimality', Journal of the American Statistical Association, Vol. 77, No. 378, pp.393-403.

Guarte, J.M. and Barrios, E.B. (2006) 'Estimation under purposive sampling', Communications in Statistics-Simulation and Computation ${ }^{\circledR}$, Vol. 35, No. 2, pp.277-284.

Hair, J.F., Black, W.C., Babin, B.J., Anderson, R.E. and Tatham, R. L. (1998) Multivariate Data Analysis, Vol. 5, No. 3, pp.207-219, Prentice Hall, Upper Saddle River, NJ.

Hoffman, D.L., Novak, T.P. and Peralta, M. (1999) 'Building consumer trust online', Communications of the ACM, Vol. 42, No. 4, pp.80-85.

Horrigan, J.A. (2008) 'Online shopping', Pew Internet and American Life Project Report, Vol. 36, No. 2008, pp.1-24.

Hsu, C.L., Lin, J.C-C. and Chiang, H.S. (2013) 'The effects of blogger recommendations on customers' online shopping intentions', Internet Research, Vol. 23, No. 1, pp.69-88.

Hsu, M.H., Chang, C.M., Chu, K.K. and Lee, Y.J. (2014) 'Determinants of repurchase intention in online group-buying: the perspectives of DeLone and McLean IS success model and trust', Computers in Human Behavior, July, Vol. 36, pp.234-245.

J.D. Power and Associates (2013) Data Privacy and Ownership: What Consumers Think, Tata Mcgraw Hill, pp.2-4 [online] https://c.ymcdn.com/sites/www.casro.org/resource/collection/ 0A81BA94-3332-4135-97F6-6BE6F6CEF475/Paper_-_Gina_Pingitore - JD_Power and Kristin_Cavallaro_-_SSI.pdf (accessed 3 May 2016).

Jacoby, J. and Kaplan, L.B. (1972) 'The components of perceived risk', in SV-Proceedings of the Third Annual Conference of the Association for Consumer Research.

Jarvenpaa, S.L. and Todd, P.A. (1997) 'Is there a future for retailing on the internet', Electronic Marketing and the Consumer, Vol. 1, No. 12, pp.139-154.

Kaplan, L.B., Szybillo, G.J. and Jacoby, J. (1974) 'Components of perceived risk in product purchase: a cross-validation', Journal of Applied Psychology, Vol. 59, No. 3, p.287.

Kim, J. and Forsythe, S. (2010) 'Factors affecting adoption of product virtualization technology for online consumer electronics shopping', International Journal of Retail and Distribution Management, Vol. 38, No. 3, pp.190-204.

Kimery, K.M. and McCord, M. (2002) 'Third-party assurances: mapping the road to trust in e-retailing', JITTA: Journal of Information Technology Theory and Application, Vol. 4, No. 2, p.63.

Kiran, R., Sharma, A. and Mittal, K.C. (2008) 'Attitudes, preferences and profile of online buyers in India: changing trends', South Asian Journal of Management, Vol. 15, No. 3, p.55.

Ko, H., Jung, J., Kim, J. and Shim, S.W. (2004) 'Cross-cultural differences in perceived risk of online shopping', Journal of Interactive Advertising, Vol. 4, No. 2, pp.20-29.

Kolsaker, A. and Payne, C. (2002) 'Engendering trust in e-commerce: a study of gender-based concerns', Marketing Intelligence and Planning, Vol. 20, No. 4, pp.206-214. 
Korzaan, M.L. (2003) 'Going with the flow: predicting online purchase intentions', Journal of Computer Information Systems, Vol. 43, No. 4, pp.25-31.

Lee, D., Park, J. and Ahn, J.H. (2001) 'On the explanation of factors affecting e-commerce adoption', ICIS 2001 Proceedings, p.14.

Lee, K. and Tan, S. (2003) 'E-retailing versus physical retailing: a theoretical model and empirical test of consumer choice', Journal of Business Research, Vol. 56, No. 11, pp.877-885.

Lee, M.K. and Turban, E. (2001) 'A trust model for consumer internet shopping', International Journal of Electronic Commerce, Vol. 6, No. 1, pp.75-91.

Lohse, G.L., Bellman, S. and Johnson, E.J. (2000) 'Consumer buying behavior on the internet: findings from panel data', Journal of Interactive Marketing, Vol. 14, No. 1, pp.15-29.

Maignan, I. and Lukas, B.A. (1997) 'The nature and social uses of the internet: a qualitative investigation', The Journal of Consumer Affairs, pp.346-371.

Marin, B., Marin, G., Perez-Stable, E., Otero-Sabogal, R. and Sabogal, F. (1990) 'Cultural differences in attitudes toward smoking: developing messages using the theory of reasoned action1', J. Appl. Social Pyschol., Vol. 20, No. 6, pp.478-493.

Masoud, E.Y. (2013) 'The effect of perceived risk on online shopping in Jordan', European Journal of Business and Management, Vol. 5, No. 6, pp.76-87.

Miller, L. and Grush, J. (1986) 'Individual differences in attitudinal versus normative determination of behavior', Journal of Experimental Social Psychology, Vol. 22, No. 3, pp.190-202.

Ming-Shen, W., Chih-Chung, C., Su-Chao, C. and Yung-Her, Y. (2007) 'Effects of online shopping attitudes, subjective norms and control beliefs on online shopping intentions: a test of the theory of planned behaviour', International Journal of Management, Vol. 24, No. 2, pp.296-302.

Miyazaki, A.D. and Fernandez, A. (2001) 'Consumer perceptions of privacy and security risks for online shopping', Journal of Consumer Affairs, Vol. 35, No. 1, pp.27-44.

Mukherjee, A. and Nath, P. (2003) 'A model of trust in online relationship banking', International Journal of Bank Marketing, Vol. 21, No. 1, pp.5-15.

Nunnally, J. (1987) Psychometric Theory, McGraw-Hill, New York, NY.

Nyshadham, E.A. (2000) 'Privacy policies of air travel web sites: a survey and analysis', Journal of Air Transport Management, Vol. 6, No. 3, pp.143-152.

Olivero, N. and Lunt, P. (2004) 'Privacy versus willingness to disclose in e-commerce exchanges: the effect of risk awareness on the relative role of trust and control', Journal of Economic Psychology, Vol. 25, No. 2, pp.243-262.

Park, H.H. and Sullivan, P. (2009) 'Market segmentation with respect to university students' clothing benefits sought: shopping orientation, clothing attribute evaluation and brand repatronage', International Journal of Retail and Distribution Management, Vol. 37, No. 2, pp.182-201.

Park, J.J. (2003) 'Understanding consumer intention to shop online: a model comparison', Dissertation Abstracts International, Vol. 64, No. 5, p.1448.

Peter, J.P. (1975) 'Behavioral decision making: a comparison of three models', NA-Advances in Consumer Research, Vol. 2.

Peter, J.P. and Tarpey, L.X. (1975) 'A comparative analysis of three consumer decision strategies', Journal of Consumer Research, Vol. 2, No. 1, pp.29-37.

Petty, R.E. and Cacioppo, J.T. (1996) Attitudes and Persuasion: Classic and Contemporary Approaches, Westview Press.

Phau, I. and Poon, S.M. (2000) 'Factors influencing the types of products and services purchased over the internet', Internet Research, Vol. 10, No. 2, pp.102-113.

Purchase Intentions (xxxx) 'Contributions from technology and trust perspectives', European Journal of Information Systems, Vol. 12, pp.41-48. 
Ramsey, R.P., Siegel, C.F. and Marshall, G.W. (1999) 'Web-based shopping versus other shopping modes: when given a choice, what do consumers prefer?', in American Marketing Association, Conference Proceedings, American Marketing Association, January, Vol. 10, p.44.

Ranganathan, C. and Jha, S. (2007) 'Examining online purchase intentions in B2C E-commerce: testing an integrated model', Information Resources Management Journal, Vol. 20, No. 4, p.48.

Rapp, J., Hill, R.P., Gaines, J. and Wilson, R.M. (2009) 'Advertising and consumer privacy', Journal of Advertising, Vol. 38, No. 4, pp.51-61.

Riegelsberger, J. and Sasse, M.A. (2001) 'Trustbuilders and trustbusters: the role of trust cues in interfaces to e-commerce applications', Proceedings of the 1st IFIP Conference on E-Commerce, E-Business, E-Government.

Salisbury, W.D., Pearson, R.A., Pearson, A.W. and Miller, D.W. (2001) 'Perceived security and World Wide Web purchase intention', Industrial Management \& Data Systems, Vol. 101, No. 4, pp.165-177.

Sarkar, A. (2011) 'Impact of utilitarian and hedonic shopping values on individual's perceived benefits and risks in online shopping', International Management Review, Vol. 7, No. 1, p.58.

Schibrowsky, J.A., Peltier, J.W. and Nill, A. (2007) 'The state of internet marketing research: a review of the literature and future research directions', European Journal of Marketing, Vol. 41, Nos. 7/8, pp.722-733.

Sinha, J. (2010) Factors Affecting Online Shopping Behavior of Indian Consumers, Masters, University of South Carolina.

Smith, J.R., Terry, D.J., Manstead, A.S.R., Louis, W.R., Kotterman, D. and Wolfs, J. (2008) 'The attitude-behavior relationship in consumer conduct: the role of norms, past behavior and self-identity', The Journal of Social Psychology, Vol. 148, No. 3, pp.311-333.

Spence, H.E., Engel, J.F. and Blackwell, R.D. (1970) 'Perceived risk in mail-order and retail store buying', Journal of Marketing Research, pp.364-369.

Taylor, J.W. (1974) 'The role of risk in consumer behavior', The Journal of Marketing, pp.54-60.

Thakur, R. and Srivastava, M. (2015) 'A study on the impact of consumer risk perception and innovativeness on online shopping in India', International Journal of Retail and Distribution Management, Vol. 43, No. 2, pp.148-166.

Tongco, M.D.C. (2007) Purposive Sampling as a Tool for Informant Selection.

TRUSTe (2015) 45\% of Americans Think Online Privacy is More Important than National Security - TRUSTe [online] https://www.truste.com/about-truste/press-room/americans-online-privacymore-important/ (accessed 3 May 2016).

Van der Heijden, H., Verhagen, T. and Creemers, M. (2003) Understanding Online.

Young, K.E. and Kim, Y.K. (2004) 'Predicting online purchase intentions for clothing products', European Journal of Marketing, Vol. 38, No. 7, pp.883-897.

Yu, D., Dong, T., Liu, R.M. and Yuan, Y.D. (2007) 'Study of types, resources and their influential factors of perceived risks in purchase online', Journal of Dalian University of Technology, Vol. 28, No. 2, pp.13-19.

Zhang, L., Tan, W., Xu, Y. and Tan, G. (2012) 'Dimensions of consumers' perceived risk and their influences on online consumers' purchasing behavior', Communications in Information Science and Management Engineering, Vol. 2, No. 7.

Zhou, L., Dai, L. and Zhang, D. (2007) 'Online shopping acceptance model-A critical survey of consumer factors in online shopping', Journal of Electronic Commerce Research, Vol. 8, No. 1, p.41.

Zimmer, J.C., Arsal, R.E., Al-Marzouq, M. and Grover, V. (2010) 'Investigating online information disclosure: Effects of information relevance, trust and risk', Information and Management, Vol. 47, No. 2, pp.115-123. 